\title{
An Updated Review on Phyto-Pharmacological and Pharmacognostical Profile Of Buchanania Lanzan : A Pharmacognostic Miracle Herb
}

\author{
Akila Elias ${ }^{1}$, Prasanna V Habbu ${ }^{2}$, Sudhir Iliger ${ }^{3}$ \\ ${ }^{1}$ Department of Pharmacognosy, RR College of Pharmacy, Bangalore, Karnataka, India \\ ${ }^{2}$ Department of Pharmacognosy, SET's College of Pharmacy, Dharwad, Karnataka, India \\ ${ }^{3}$ Department of Pharmaceutics, SET's College of Pharmacy, Dharwad, Karnataka, India \\ Corresponding Author email id: akilapharma.23@gmail.com
}

$\begin{array}{ll} & \text { ABSTRACT } \\ \text { Article Info } & \begin{array}{l}\text { Buchanania lanzan (Anacardiaceae) is a miracle herb widely used by Indian } \\ \text { tribes for treating various diseases. Aim of the current review is to search } \\ \text { Volume 8, Issue 6 }\end{array} \\ \text { Page Number : 298-310 } & \begin{array}{l}\text { literature for the pharmacological properties, pharmacognostic studies and } \\ \text { phytochemical investigation of Buchanania lanzan. The compiled data may be }\end{array} \\ \text { Publication Issue } & \begin{array}{l}\text { helpful for the researchers to focus on the priority areas of research yet to be } \\ \text { discovered. Complete information about the plant has been collected from } \\ \text { November-December-2021 } \\ \text { various books and journals. Particulars of pharmacological activities, } \\ \text { phytochemical isolation, toxicity studies etc. ongoing and emerging areas of } \\ \text { Accepted : 01 Dec 2021 } \\ \text { Published : 08 Dec 2021 }\end{array} \quad \begin{array}{l}\text { pharmach of this plant, especially in the field of phytomedicnes and } \\ \text { Keywords : Buchanania lanzan, Anacardiaceae, phytopharmacological review, } \\ \text { safety. }\end{array}\end{array}$

\section{INTRODUCTION}

\section{Importance of Herbal Medicines}

The word "herb" has been derived from the Latin word, "herba" and an old French word "herbe". Now a days, herb refers to any part of the plant like fruit, seed, stem, bark, flower, leaf, stigma or a root, as well as a non-woody plant. Earlier, the term "herb" was only applied to non-woody plants, including those that come from trees and shrubs. These medicinal plants are also used as food, flavonoid, medicine or perfume and also in certain spiritual activities.

Plants have been used for medicinal purposes long before prehistoric period. Recently, WHO (World Health Organization) estimated that 80 percent of people worldwide rely on herbal medicines for some aspect of their primary health care needs. According to WHO, around 21,000 plant species have the potential for being used as medicinal plants. 
As per data available over three-quarters of the world population relies mainly on plants and plant extracts for their health care needs. More than $30 \%$ of the entire plant species, at one time or other were used for medicinal purposes. It has been estimated, that in developed countries such as United States, plant drugs constitute as much as $25 \%$ of the total drugs, while in fast developing countries such as India and China, the contribution is as much as $80 \%$. Thus, the economic importance of medicinal plants is much more to countries such as India than to rest of the world. These countries provide two third of the plants used in modern system of medicine and the health care system of rural population depend on indigenous systems of medicine.

Treatment with medicinal plants is considered very safe as there is no or minimal side effects. These remedies are in sync with nature, which is the biggest advantage. The golden fact is that, use of herbal treatments is independent of any age groups and the sexes.

Medicinal plants such as Aloe, Tulsi, Neem, Turmeric and Ginger cure several common ailments. These are considered as home remedies in many parts of the country. It is known fact that lots of consumers are using Basil (Tulsi) for making medicines, black tea, in pooja and other activities in their day-to-day life.

In several parts of the world many herbs are used to honour their kings showing it as a symbol of luck. Now, after finding the role of herbs in medicine, lots of consumers started the plantation of tulsi and other medicinal plants in their home gardens. In India, use of herbal medicine is perhaps more prevalent than western countries. Some of the examples of herbal medicines are Echinacea, Kava, Valerian, Gingko Biloba, Ginseng and St. John's Wort.

\section{Plant description}

Buchanania lanzan Spreng. is a member of the family Anacardiaceae, originated in the Indian sub-continent, is an excellent multipurpose tree species. Traditional indigenous knowledge reveals the immense value of almost all parts of the plant i.e. roots, leaves, fruits, seeds and gum for various medicinal uses. [Figures 1, 2 and 3] Buchanania lanzan is a deciduous tree which produces seeds that are edible to humans. It is known as Chironji (or Charoli). These almond-flavoured seeds are used as a cooking spice primarily in India.

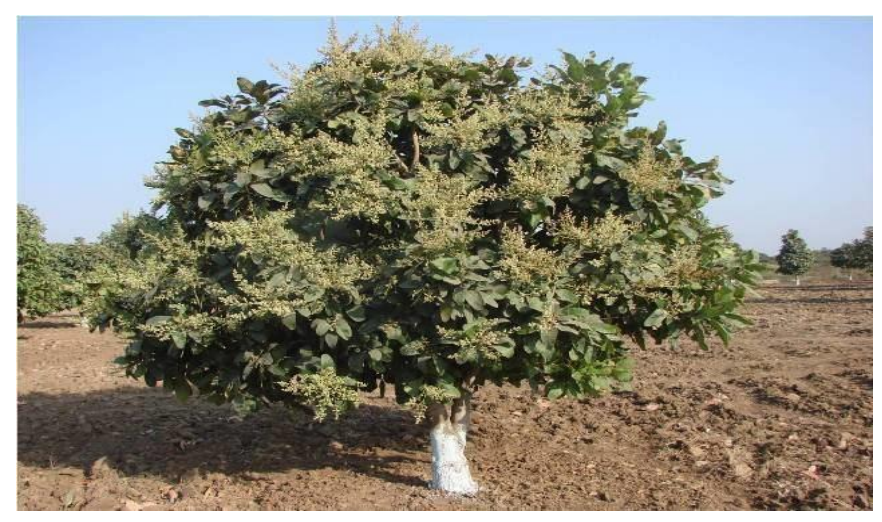

Figure 1: Tree of Buchanania lanzan Spreng.

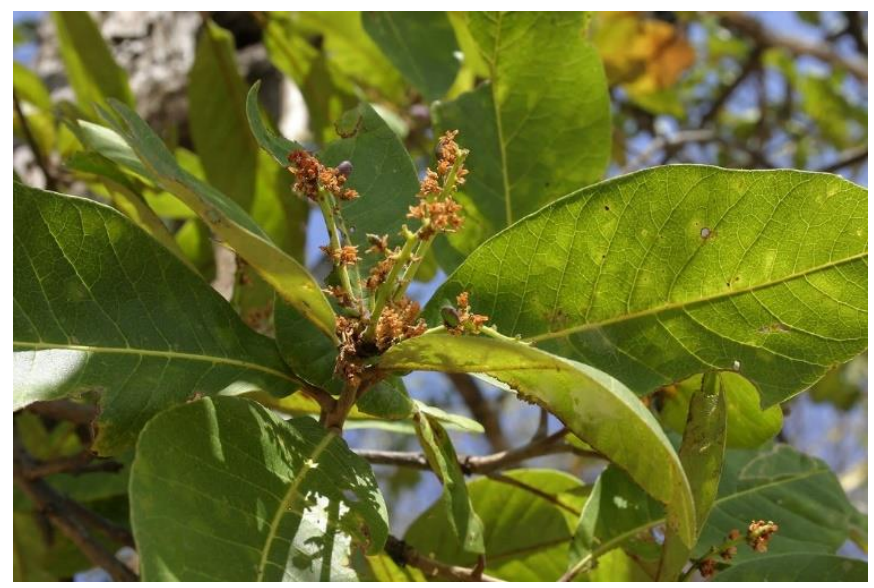

Figure 2: Leavesof Buchanania lanzan Spreng. 


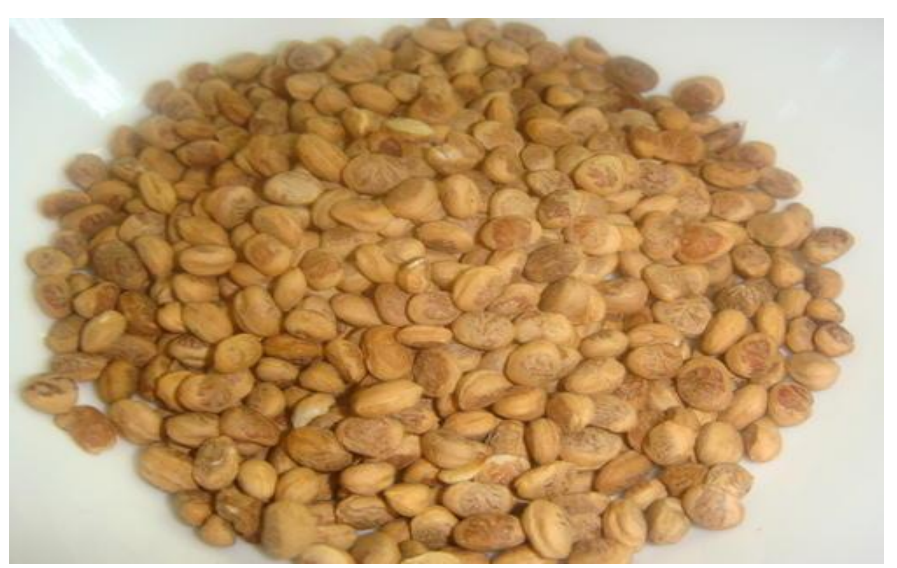

Figure 3: Seeds of Buchanania lanzan Spreng.

\section{Scientific classification}

Kingdom: Plantae

Phylum - Tracheophyta

Class - mangnoliopsida

Order : Sapindales

Family: Anacardiaceae

Subfamily Anacardioideae

Genus : Buchanania

Species : B. lanzan

Binomial name Buchanania lanzan

\section{Synonyms}

Buchanania latifolia ROXB. almondette, cheronjee, cuddapah almond.

\section{General description}

English Name: almondette, cheronjee, cuddapah almond

Hindi Name : achar, char, charoli, charoli-kernel, chiraunji, chironji,

Kannada Name : chaara pappu, chaaruvaala, chalaali, char, charoli,

Sanskrit Name : akhatta, bahulavalkala, cara, chara, charaka, dhanu, dhanushpatta,

Tamil Name : modama, moraimaram, morala, mudaikkai, mudaima

Parts Used : roots, leaves, fruits, seeds

\section{Traditional uses}

Traditional indigenous knowledge reveals the immense value of almost all parts of the plant i.e. roots, leaves, fruits, seeds and gum for various medicinal uses. The gum from the tree is used against leprosy in traditional medicine. ${ }^{1}$ Charoli seeds are used in the Ayurveda and Unani systems of medicine. The roots are acrid, astringent, cooling, depurative and constipating. They are useful in the treatment of diarrhoea. ${ }^{2}$ The fruits are used in treating coughs and asthma. The seeds are used as expectorant and tonic. The oil extracted from kernels is applied on skin diseases $^{3}$ and also used to remove spots and blemishes from the face. The juice of the leaves is digestive, expectorant, aphrodisiac, and purgative. ${ }^{4}$ The gum after mixing with goat milk is used as an analgesic.

\section{Morphology of the plant}

Sub deciduous trees, to $18 \mathrm{~m}$ high, bark $10-12 \mathrm{~mm}$ thick, surface black or dark brown, rough, tessellate the cracks being deep and narrow, somewhat resembling crocodile hide; blaze red. Leaves simple, alternate, estipulate; petiole $12-22 \mathrm{~mm}$, stout, glabrous; lamina 10-23.5 x 5-12 cm, broadly oblong, base round or acute, apex obtuse or emarginate, margin entire, glabrous above and densely tomentose beneath, coriaceous; lateral nerves 10-20 pairs, pinnate, prominent, pubescent, secondary laterals prominent, intercostae reticulate, prominent. Flowers bisexual, greenish-white. ${ }^{5}$

\section{Growing Season and Type}

The tree is leafless or nearly so, for a very short time during the summer season. Flowers appear from January to March and their colour is greenish-white. Fruits ripen in the months of May-June. ${ }^{6}$ The fruits become red after ripening. The fruit collection starts from mid-April and ends by mid-June, but its harvesting is generally finished in 15-20 days only. The harvesting period may vary with the purpose of fruit collection indifferent agro-climatic zones. Early harvesting result into low fruit/seed setting and poor germination potential. In most parts of Madhya Pradesh, fruits of Buchanania lanzan are harvested before ripening. As a result, it fetches much lower 
price in the marked because of small seed size and low seed quality even. This tree is lopped frequently for the purpose of huge and rapid collection. In forests, its natural regeneration is very scanty due to unscientific and pre-mature harvesting of its seeds and site degradation on account of growing biotic pressure. $^{7}$

The seeds are the major source of regeneration of $B$. lanzan in India. The major problem in the reforestation of $B$. lanzan is the low germination frequency of seeds due to seed borne fungal contamination (endogenous) during storage of seeds. Moreover, the fungal attack by Fusarium sp. (wilting disease) is common after sowing the seeds in soil. ${ }^{8}$ The seeds exposed to sunlight fail to germinate and soon lose their viability. Another hindrance is the presence of a hard seed coat which leads to low germinating capability. Therefore, in order to ensure further supply of this commercially useful tree species, other breeding methods are required. Plant tissue culture is one of the most effective techniques to micro propagate a plant of interest. ${ }^{9}$

\section{Distribution}

Seven species of Buchanania have been reported in India of which two B. lanzan (Syn. B.latifolia) and B. axillaries (Syn. angustifolia) produce edible fruits. $B$. lanceolata is an endangered species. It is found in the ever green forests of Kerala. B. platyneura is found in Andaman only. Other species of the genus are $B$. lucida, B. glabra, B.accuminata. ${ }^{10}$

Among these species Buchanania lanzan Spreng is most important and widely distributed species in India. This species was first described by Mr. Hamilton, a forester in 1798 in Burma and the genus Buchanania was named after him. It was originated in the Indian sub-continent, and is found in India, Burma, Nepal and few other countries. ${ }^{11}$

It is a valuable tree species found in mixed dry deciduous forest throughout the greater part of India excluding eastern Himalayan forests and arid regions of north India. The species is native to India. It is a main species of Southern and northern tropical dry deciduous and Northern dry mixed 4 deciduous forest type widely distributed in the state of Madhya Pradesh, Chhattisgarh, Jharkhand, South east Uttar Pradesh and part of Gujarat, Rajasthan, Orissa, Andhra Pradesh Karnataka and Maharashtra. It is an important tree species of Vindhyan Zone (Mirzapur and Sonbhadra districts) and Budelkhand region of Uttar Pradesh. ${ }^{12}$

\section{Ayurvedic properties}

Chironji - Buchanania lanzan, charoli is called priyala in Ayurveda. It is used as a cooking spice. It is aphrodisiac, nourishing, cardiac tonic but it may cause indigestion.

- Guna (qualities): Snigdha-unctuous, oily, Guru (heaviness),Sara - induces mobility, causes diarrhea, purgation, relives constipation

- $\quad$ Rasa (taste): Madhura - Sweet

- Vipaka: Madhura - Sweet

- Veerya: Sheeta-Coolant

- Effect on Tridosha: Balances Vata and Pitta

The marrow of priyala is sweet and aphrodisiac. It treats vitiation of pitta and vata dosha, is cardio tonic, unctuous, cause's constipation, difficult to digest and increase ama.

Sanskrit Names: Priyala, Piyala, Kharskandha, Bahulvalkala, Tapaseshtha, Sannakadru Dhanushpat.

Action and Uses: Vata pitta samak, Kustaghan,Sothahar, Sarak, trisasamak, Snigdha,Guru kafanisarak, Mutral, Vajekarn, Daha saman,brindhan, balya.

Doses: Bark decoction - 56 to $112 \mathrm{ml}$

Seeds -12 to $24 \mathrm{~g}$. 


\section{Ayurvedic Formulations}

Common Ayurvedic Formulations of priyala with their Indications

Chandanadi Taila - a natural coolant oil. It is used to relieve burning sensation, dizziness, etc.

Ashoka Ghrita - Herbal ghee used in gynaecological disorders.

Puga Khanda - used in the treatment of vomiting, gastritis, dyspepsia, abdominal colic pain, dizziness.

\section{Phytochemical investigation}

The kernels contains moisture, 3.0; protien, 19.0; fat,59.0; Àbers, 3.8; carbohydrates 12.1; and minerels 3.0 g/100 gm; calcium, 279.0; phosphours, 528.0 (phytin phosphorus, 158.0); iron, 8.5; oxalic acid, 2.0; magnisum, 373.0; sodium, 10.2; potasium, 436.0; copper, 0.86; sulphur, 186.0; chorine, 25.0; thiamine, 0.69; riboÁavin, 0.53; niacin, 1.5 ; vitamins $C$, 5.0 $\mathrm{mg} / 100$; lipid $65.6 \%$ comprised mainly of neutral lipids $90.4 \%$ consisting mostly of triacylglycerols 82.2 $\%$, free fatty acid $7.8 \%$ and small amount of diacylglycerols, monoacylglycerols and sterols. ${ }^{13}$

The leaves contain quercetin, gallic acid, kaempferol, kaemferol-7-O-glucoside, quercetin-7-O-rhamnoside, quercetine-3-O-rhamnogluvosside and myricetin 3rhamnoside. Two major class of secondary metabolites were detected Glycosides, Phenolic compounds from leaves. ${ }^{14}$

Glycoside, myricetin 3-rhamnoside-3-galactoside, has been isolated from leaves of B. lanzan. Its structure was established from spectroscopic and chemical evidence. ${ }^{15}$

Three major chemical constituents isolated from the methanolic extract of leaves, characterized based on chemical tests and spectral analysis such as infrared, $\mathrm{H}$ nuclear magnetic resonance, mass spectroscopy were epinitol, vomicine, and celidoniol. ${ }^{16}$

\section{Pharmacognostic studies}

A detailed pharmacognostic morphological and microscopical work for the seeds and barks of B.lanzan was carried out.

\section{Macroscopic characters}

B. lanzan barks are $10-12 \mathrm{~mm}$ thick, surface black or dark brown, rough, tessellate the cracks being deep and narrow, somewhat resembling crocodile hide; blaze red. Leaves are broadly oblong, rounded base with a blunt tip and have straight, parallel veins. ${ }^{17}$

The seeds colour is brownish, odour pleasant and sweetish, oily taste. Seed is oblong to rectangular, 4 to $9 \mathrm{~mm}$ in length, 5 to $7 \mathrm{~mm}$ in width, dorsiventral convex. Oval to circular fan shaped brown patch with white streaks. A ridge runs throughout the edge. ${ }^{18}$

\section{Microscopical features ${ }^{18,19}$}

The anatomy of bark and seed was studied by taking the transverse sections followed by staining.

The transverse section of bark shows the outer most layers is cork. Cork is 5-9 layers, thin walled rectangular cells, some with yellowish matter. Phellogens are two layers of colourless rectangular cells. Phelloderms are 5-10 layers, thin walled somewhat rectangular cells, at times arranged in radial rows. The parenchymatous cells contain rhomboidal crystals and a few starch grains. Cortex is wide, interspersed with groups of lignified, pitted, stone cells of large lumen and of various shapes (rectangular to elongate) and sizes. The cortical parenchyma surrounding the stone cells and as well the stone cells themselves contain rhomboidal crystals. Starch grains are present in cortical parenchyma. One or two groups of non-lignified pericyclic fibres are seen in the cortex. Secondary phloem consists of phloem parenchyma, medullary rays and groups of stone cells arranged in tangential rows separated by medullary rays. The stone cells in the secondary phloem are encircled by a sheath of parenchyma containing rhomboidal crystals of calcium oxalate. Medullary rays are 1-3 seriate, wide towards the 
outside and consist of thin walled radially elongated parenchymatous cells. Phloem parenchyma and medullary ray cells contain starch grains.

Seed transverse section shows a layer of epidermis of the testa, usually getting peeled off from the inner 2 to 5 rows of lignified pitted parenchymatous tissue traversed with long spiral xylem vessels especially when the section is through raphe and few tangentially running narrow small sclereids. A pigment layer lies underneath this followed by collapsed parenchymatous celled layer. Endosperm is narrow, consisting of 3 to 6 rows of thick-walled parenchymatous cells, Cells lying underneath this are collapsed, cotyledons exhibit usual structure, its few outermost cell lying underneath the epidermis being palisade like, other cells are loaded with fixed oil, protein and starch grains.

\section{Powder microscopy}

In the powder characteristics of bark powder, it was observed that the fibers are showing pink colour with phloroglucinol and conc. $\mathrm{HCl}$. Cork cells are thin walled, few colourless and few with yellowish brown matters. Stone cells are rectangular to oval in shape, walls atriated, pitted and lignified surrounded by sheath of parenchymatous cells containing calcium oxalate prism. Medullary rays at right angle. Few simple starch grains are reported.

The seed powder shows elongated thick-walled sclereids, spiral, reticulate and annular vessels, small fragments of pigment cells in surface view, Epidermis of testa in surface view, Cotyledon with layer of upper epidermis, Cotyledon with layer of lower epidermis, Pitted cells of raphe, Pigment layer of testa overlapping with endosperm in surface view and Upper epidermis of cotyledon overlapping with collapsed celled layer and vessels in surface view.

\section{Pharmacological studies}

\section{Wound healing activity with a focus on antimicrobial} and anti-biofilm properties

The root extract (B. lanzan) was evaluated for its wound healing properties against excision and incision models of wound repair. Topical application of B. lanzan (10\% w/w ointment) significantly enhanced wound healing process as observed in both excision and incision models and such significant activity was observed from the 9th day. Whereas Soframycin displayed significant wound healing activity from the 6th day. This treatment increased the rate of wound contraction, thereby decreasing the time of healing in comparison to control group of animals. It'd be interesting to notice that $10 \% \mathrm{w} / \mathrm{w}$ ointment produced faster onset of the healing process and also reduced the period of time for the entire healing to occur. The extract also facilitated the proliferation of epithelial cells after wounding (from wound edges), thus accelerating re-epithelialization and wound closure. It had been found that root extracts of B. lanzan revealed significant inhibition against all tested pathogens. B. lanzan displayed antimicrobial activity against Gram positive (MIC $0.625 \mathrm{mg} / \mathrm{mL}$ ) and Gram negative (MIC 0.625-1.25 $\mathrm{mg} / \mathrm{mL}$ ). B. lanzan was ready to reduce biofilm formation and also caused disruption of preformed biofilms during a manner almost like ciprofloxacin. However, gentamicin was found to be ineffective against biofilms formed by Gram negative organism. Consistent with the fractional inhibitory concentration index, B. lanzan displayed synergistic activity when it had been combined with gentamicin. it may be concluded that the root extract of $\mathrm{B}$. lanzan revealed significant wound healing potential, which was supported and well correlated with pronounced antibacterial activity of the tested plant parts. ${ }^{20}$

\section{Effect on hematological indices}

A study was carried out to investigate the effects of methanolic extract of Buchanania lanzan Spreng seeds on hematological indices. Eighteen male albino 
Wistar rats were divided into three groups, six in each Group I animals received distilled water, Group II and III were treated with an oral dose of $1000 \mathrm{mg}$ oil $/ \mathrm{kg}$ and $2000 \mathrm{mg}$ oil $/ \mathrm{kg}$ of extract, respectively, for 7 days. At the end of the study, blood was collected and evaluated for packed cell volume (PCV), hemoglobin $(\mathrm{Hb})$ concentration, and red blood cell $(\mathrm{RBC})$ and white blood cell (WBC) counts. There was a significant dose-dependent increase in the hematological indices such as PCV, $\mathrm{Hb}, \mathrm{RBC}$, and WBC count in the treatment group. The improvement of $\mathrm{PCV}, \mathrm{Hb}$, and $\mathrm{RBC}$ values is an indication of the anti-anemic effect which may be due to the stimulation of $\mathrm{RBC}$ production in bone marrow. ${ }^{21}$

\section{Anti- Microbial activity}

The leaf extract of Buchnania Lanzan having antibacterial and antifungal activities and this was comparable to that of the standard Antibiotics like ampicillin Penicillin-G and Streptomycin (10 Units/disc) and Fluconazole (10mg). The methanol leaf extract of Buchanania lanzan had more antibacterial properties in comparison to extracts of petroleum ether, chloroform and water.. The maximum antibacterial activity was observed in $E$. coli followed by $P$. aeruginosa and $S$. aureus, while in case of antifungal activity Aspergillus spp. was found to be more sensitive than Penicillium. ${ }^{22}$

\section{Anthelmintic activity}

Anthelmintic activity was performed on Pheritima posthuma using Albendazole as standard and alcoholic extract was more effective as it takes less time for paralysis and death of earthworms as compared to ethyl acetate and chloroform extracts. ${ }^{23}$

\section{Anti diarrhoel activity}

Castor oil induced diarrhoeal test was used to assess the antidiarrhoeal activity and gastrointestinal tract transit of charcoal meal test was used to assess the antipropulsive activity of the alcoholic extract of Buchanania lanzan Spreg roots. The alcoholic extract of Buchanania lanzan Spreg roots significantly reduced faecal output in castor- oil induced diarrhoea and also significantly reduced the number of diarrhoeal episodes and significantly delayed the onset of diarrhoea induced by castor oil and significantly reduced the number of animals exhibiting diarrhoea. Buchanania lanzan Spreg significantly reduced the intestinal propulsion of charcoal meal in mice. ${ }^{24}$

\section{Anti-Ulcer Activity}

Peptic ulcer disease is a serious gastrointestinal disorder which needs a well-targeted therapeutic strategy. The ethanolic root extract of B. lanzan is evaluated for its antiulcer activity. Various concentrations of the ethanolic root extract (200 and $400 \mathrm{mg} / \mathrm{kg}$ orally) has been evaluated in mice and pylorus ligation induced ulcer in rats for its anti-ulcer activity. It is observed that the ethanolic extract showed a dose-dependent protection and significant protection of ulcer index in both the models as well as also inhibited the pylorus ligation-accumulated gastric secretion. Thus, the extract is in possession of good preventive and therapeutic action on the gastric ulcers. ${ }^{25}$

\section{Effect on cyclophosphamide induced genotoxicity and oxidative stress}

Buchanania lanzan bark shows High content of polyphenols, in vitro antioxidant activity and traditional use of this plant in prevention of cancer, compel to investigate the effect against cyclophophomide-induced genotoxicity and oxidative stress in mice using ethanolic bark extract. The prevalence of micronuclei in bone marrow, the extent of lipid peroxidation, reduced glutathione and the status of the antioxidant enzymes, superoxide dismutase and catalase in liver of mice were used as intermediate biomarkers for chemoprotection. The animals are Pre-treated with B. lanzan extract 250, 500 and $1000 \mathrm{mg} / \mathrm{kg}$, p.o., daily for 7days significantly reduced the chromosomal damage and 
lipid peroxidation with concomitant changes in antioxidants and detoxification systems. Lipid peroxidation and associated compromised antioxidant defenses in cyclophosphamide treated mice were observed in the liver. This study concludes that the presence of chemopreventive phytoconstituents inside the crude extract offering safety against cyclophosphamide brought on genotoxicity and oxidative strain in mice. ${ }^{26}$

\section{Antidiabetic and Antihyperlipidemic Activity}

Diabetes mellitus is a chronic metabolic disease caused by an absolute or relative lack of insulin and or reduced insulin activity, which results in hyperglycemia and abnormalities in carbohydrate, protein and fat metabolism. Hyperlipidemic condition is metabolic complication of both clinical and experimental diabetes. The antidiabetic and antihyperlipidemic activity of methanolic extract of Buchanania lanzan is studied in Streptozotocin induced types I and II diabetic rats. Methanolic extract of B.lanzan in the dose of (100 and $200 \mathrm{mg} / \mathrm{kg}$ p.o) is administered for 21 days which significantly ( $\mathrm{p}$ $<0.05$ ) lowered blood glucose levels in a dosedependent manner. Therefore,its concluded that the antidiabetic, antihyperlipidemic activities of this plant may due to its active constituents, including glycosides, carbohydrates, sterols and flavonoids. ${ }^{27}$

\section{Anti - inflammatory activity}

The anti-inflammatory activity of methanolic extract of the leaves of Buchanania lanzan was investigated in animal models using Carrageenan-induced rat paw oedema. The animals were pretreated with methanolic extracts in concentration of (ME$10 \mathrm{mg} / \mathrm{kg}, 20 \mathrm{mg} / \mathrm{kg}, 30 \mathrm{mg} / \mathrm{kg}, 40 \mathrm{mg} / \mathrm{kg}$, and $50 \mathrm{mg} / \mathrm{kg}$ ) were given by (i.p) route 30 minutes before carrageenan injection (phlogistic agent) of $0.1 \mathrm{ml}$ dose (i.p);.Carrageenan was injected into the sub plantar tissue of left hind paw of each rat and Swellings of foot is measured at using plethysmometer which is compared with standard aspirin at different doses. The extract showed significant anti-inflammatory activity in a dose dependent manner. ${ }^{28}$

\section{Diuretic Activity}

A comparative study was performed to evaluate diuretic effect of Priyala fruits (Buchanania angustifolia, Buchanania lanzan ) and its fractions in rats using Lipschitz et al., method. both B. angustifolia and B. lanzan alcoholic extracts has shown significant diuresis with a diuretic index of 3.69 and 3.61 respectively at the dose of $500 \mathrm{mg} / \mathrm{kg} \mathrm{BW}$. Whereas, fractions have shown moderate diuresis with the diuretic index ranging between 2.19 to2.69. From this study, it is concluded that the Buchanania angustifolia was found to be better diuretic than Buchanania lanzan. at a dose of $500 \mathrm{mg} / \mathrm{kg}$ which appeared to be comparable with that of the standard drug Frusemide. ${ }^{29}$

\section{Analgesic and Antipyretic Activity}

Pyrexia or fever produce as body's natural defense mechanism in response to any infection ordisease. In pyrexia, an environment is created inside the body in which the infectious pathogens and dam-aged tissues are unable to survive. The aqueous and ethanolic extracts of seeds of Buchanania lanzan Spreng. is subjected to evaluation of analgesic and antipyretic activities using brewer yeast induced pyrexia and acetic acid induced writhing methods respectively. This study is carried out using Albino mice. The animals were treated with different concentrations of extracts i.e 125, 250 and $500 \mathrm{mg} / \mathrm{kg}$ and it is observed that the extracts showed dose dependant decrease in temperature with increasing potency from 125 to 500 $\mathrm{mg} / \mathrm{kg}$. The better antipyretic activity is observed in aqueous extract of seed at dose of $500 \mathrm{mg} / \mathrm{kg}$ which was moderate as compared to the standard. ${ }^{30}$ 


\section{Antioxidant Activity}

In this present study the antioxidant activity of the alcoholic extracts was evaluated quantitatively using the polyphenolic content of the Buchanania lanzan seeds were which is produced by conventional extraction techniques - cold maceration and soxhlet extraction. The Total phenolic and flavonoid content has been determined in which The cold macerated extract gives higher phenolic and flavonoid content whereas soxhlet extract had low phenolic and flavonoid contents. The anti-oxidant activity is evaluated by DPPH and FRAP assays. In DPPH assay, cold macerated extract showed better anti-oxidant activity of 50\% inhibition at a concentration of 273.62 $\pm 1.61 \mu \mathrm{g} / \mathrm{mL}$ in comparative with soxhlet extract which shows $50 \%$ inhibition at $670.7 \pm 4.03 \mu \mathrm{g} / \mathrm{m}$. reducing ability of these extracts also evaluated. The results indicated that the reducing ability of cold macerated extract was high as compared to soxhlet extract. Hence, the cold macerated alcoholic extract was found better antioxidant with a higher phenolic and flavonoid content. ${ }^{31}$

\section{DNA Protective Activity}

Most anti-cancer agents are believed to act mainly by quenching the free radicals or by direct interaction with DNA. ${ }^{32}$ B. lanzan methanolic extract is investigated against DNA damage. In this study plasmid DNA (pBR322) was exposed to Fenton reaction for $30 \mathrm{~min}$ at $37 \mathrm{oC}$. Fenton reaction caused a change (super shift) in native double stranded DNA band (Form I) to single-stranded, nicked DNA (Form II) confirmed in agarose gel electrophoresis. In contrast, DNA pre incubated with different concentration viz., 10, 25, 50 $\mathrm{g}$ of the extract prevented the scission when subjected to Fenton reagent under similar conditions as above. The DNA nicking assay gives the ability of the extract to quench the free radicals which is harmful for DNA. ${ }^{33}$

\section{Cardio Protective Activity}

The cardioprotective effect of ethanolic extract of Buchanania lanzan Spreng. (EEBL) is investigated against isoproterenol induced myocardial infarction in rats by studying myocyte injury markers, antioxidant defense system, serum and electrocardiographic changes. Myocardial infarction in rats was induced by isoproterenol administration $\left(200 \mathrm{mg} / \mathrm{kg}\right.$, s.c.) at an interval of $24 \mathrm{~h}$ on $29^{\text {thand }}$ $30^{\text {th }}$ day. On $30^{\text {th }}$ day $E C G$, biochemical parameters were assessed. Isoproterenol administration showed changes in ECG pattern, including ST-segment elevation (diagnostic of myocardial infarction) increase in the serum levels of cardiac injury markers (Creatine kinase-MB, lactate dehydrogenase, aspartate transaminase and alanine transaminase), decreased antioxidant defense system in the heart. EEBL pre-cotreatment prevented almost all the parameters of isoproterenol induced myocardial infarction in rats. Results of the present study suggest that EEBL has a significant effect on the protection of the heart against isoproterenol induced myocardial infarction through maintaining endogenous antioxidant enzyme activities. $^{34}$

\section{Memory booster}

Alzheimer's disease is a progressive neurodegenerative brain disorder that occurs gradually and results in memory loss, unusual behavior, personality changes, and ultimately death. ${ }^{35}$ Biochemical abnormalities such as reduction of acetyltransferase, acetylcholine biosynthases and increase in acetyl cholinesterase (AChE), and metabolism are strongly associated the degree of cognitive impairment. ${ }^{36}$ Petroleum ether extract of seeds of B.lanzan (PEB) $(500 \mathrm{mg} / \mathrm{kg}$, oral) is studied for its neuro-psychopharmacological effect in experimental rats. Activity of seeds extract on memory acquisition and retention is studied using elevated plus maze and step down apparatus models, 
and AChE enzyme level at discreet parts of brain is also estimated. Administration of PEB $(500 \mathrm{mg} / \mathrm{kg})$ to positive control and treated groups showed significant reduction in transfer latency in elevated plus maze, increase in step down latency in step down apparatus models and reduction of acetylcholine esterase enzyme activity in different regions of the brain as compared with the other groups. ${ }^{37}$

\section{Applications in Novel Drug Delivery System}

\section{Zidovudine Nanosuspensions Using a Novel Bio Polymer}

A novel bio material is isolated from the seeds of Buchanania lanzan by simplified economical and it is evaluated its potency for sustained drug delivery by formulating various Nano suspension using methylene chloride as organic solvent and biomaterial. According to OECD guidelines, five different formulation were prepared using different ratios of biomaterial by solvent evaporation. The Nano suspension formulations were subjected for various evaluation parameters like particle size and shape, drug content, entrapment efficacy and \% transmittance and in-vitro drug release studies. On the basis of in-vitro release studies, the formulation with increased amount of bio polymer (FNS4) was found to be better than the other formulations and it was selected as an optimized formulation. In-vitro studies revealed that FNS4 followed perfect zero first order kinetics release. It was observed that the increasing the proportion of bio polymer increases the rate of release of zidovudine. ${ }^{38}$

\section{Oral Mucoadhesive Tablets}

Oral mucoadhesive drug delivery system formulated using Buchanania lanzan spreng seeds mucilage and it was evaluated for its mucoadhesive properties in compressed tablet, containing losartan potassium. Four different concentrations of Mucilage was used i.e., 21, 42 and 55\% w/w and Granules were prepared using polyvinylpyrrolidone as binding agent. These tablets were subjected to its physical property evaluation followed by in vitro dissolution and swelling index was determination. The isolated mucilage bioadhesive strength was compared with Guar gum and HPMC E5LV, which was used as standard mucoadhesive agent concentration which was measured on the modified physical balance. Result revealed that tablets had good physiochemical properties, and drug release was retarded as concentration of mucilage was increased and it showed relative effect on release of drug from formulation. All the formulations were subjected to stability studies for three months, all formulations showed stability with respect to release pattern. From these results, it is concluded that the seed mucilage of BL can be a suitable excipient for oral mucoadhesive drug delivery systems. ${ }^{39}$

\section{Biostabilizer in Selegiline Bionanosuspensions}

selegiline-loaded bio-nanosuspensions are formulated using biopolymer isolated from seeds of Buchanania lanzan, used as biostabilizer and standard stabilizer (hydroxypropyl methylcellulose) by sonication solvent evaporation method with different ratios $(1 \%$, $2 \%, 3 \%, 4 \%$, and $5 \%$ ) and it is evaluated for particle size, polydispersity index, zeta potential, $\mathrm{pH}$ stability studies, percentage entrapment efficacy, in vitro drug release, and stability studies. . From this study it is found that The biopolymer isolated from the seeds provided excellent stability and particle size for the best formulation. The best formulation was found to be polydispersity index of 0.43 with zeta potential of $-5.12 \mathrm{mV} .{ }^{40}$

\section{Ophthalmic biofilm from seed}

A novel biomaterial from the seeds of $B$. lanzan was isolated and its biofilm forming ability by formulating various ophthalmic films using polyethylene glycol 400 as plasticizer and biomaterial as biofilm former was evaluated. Four formulations were prepared using biofilm former in different ratios by film casting technique. The formulated ophthalmic films were 
subjected to various evaluation parameters such as weight variation, uniformity thickness, folding endurance, hardness, surface $\mathrm{pH}$, swelling index, and in vitro release studies. The drug release studies from the formulated ophthalmic films exhibited a promising stability, swelling index, folding endurance, and sustainability for a period of $8 \mathrm{hrs}$. The isolated biofilm former acts as a novel film former for formulating various ophthalmic films. ${ }^{41}$

\section{Transdermal patches using B.lanzan (Spreng) Seed Oil as Penetration Enhancer}

The permeation enhancement properties of Buchanania lanzan spreng seed oil was evaluated using Ethyl cellulose transdermal patches of Glipizide using some essential oils as penetration enhancers. Effect of drug loading and penetration enhancers was investigated on the in vitro permeation of drug through rat skin. Incorporation of essential oils increased the moisture content, moisture uptake ability and permeation of Glipizide across skin barriers. Buchanania lanzan spreng seed oil is found to be most effective when compared with others. it was also concludes that the seed oil can be used in permeation enhancement of various types of tropical preparation. ${ }^{42}$

\section{Conclusion}

The above review reveals that the plant is traditionally used for various therapeutic purpose. The plant was found to be potent analgesic, antiinflammatory, Cardio protective, anthelmintic, antibacterial, antifungal and cytotoxic agent. The phytoconstituents which are present in the plant are mainly phenols which are responsible for the actions. More research is needed to isolate the constituents responsible for the biological actions. It was also observed that no clinical trials have been done so far. So from the current review of literature and ayurvedic text it was concluded that the plant is having high medicinal value. The traditional and ethnomedicinal literatures showed that the plant is very effective and safe for medicinal uses. By using the reverse pharmacological approaches in natural drug discovery a potent and safe drug can be investigated from the plant for various chronic diseases like liver diseases, cancer, arthritis, and other inflammatory diseases.

\section{REFERENCES}

[1]. Chaturvedi Dev Sharan, Chaturvedi Barkha. Pharmacological Importance of Buchnania Lanzan Spreng. Journal of Molecular Pharmaceuticals and Regulatory Affairs. 2019:1(2):25-28.

[2]. Pandey GP. Effects of gaseous hydrogen fluoride on leaves of Terminalia tomentosa and Buchanania lanzan trees. Environmental Pollution Series A, Ecological and Biological. 1985;37(4):323-34.

[3]. Das D, Agrawal VS. Fruits drug plants of India. Kalyani Publishers, New Delhi.1991;250.

[4]. Kala CP. Aboriginal uses and management of ethnobotanical species in deciduous forests of Chhattisgarh state in India. Journal of Ethnobiology and Ethnomedicine. 2009 ;5(1):20.

[5]. Malik SK, Chaudhury R, Panwar NS, Dhariwal OP, Choudhary R, Kumar S. Genetic resources of Chironji (Buchanania lanzan Spreng.): a socioeconomically important tree species of central Indian tribal population. Genetic resources and crop evolution. 2012;59(4):615-23.

[6]. Troup RS. The silviculture of Indian trees. Dehra Dun, IN: International Book; 1986.

[7]. Sharma A. Scientific harvesting for quality seed collection of Buchanania lanzan Spreng. for its conservation and sustainable management----case study of Chhindwara, Madhya Pradesh, India. Int J Bio-Sci Bio-Technol. 2012 ;4(1):65-74.

[8]. Sharma N, Ghosh R, Nigam M. Toxigenic fungi associated with stored fruits of Chironji. Indian Phytopathol. 1998;51:284-6.

[9]. Shende S, Raj M. Multiple shoot formation and plant regeneration of a commercially-useful plant, 
Buchanania lanzan (Spreng). Plant Biotechnol. 2005;22(1):59-61.

[10]. Rajput BS, Gupta D, Kumar S, Singh K, Tiwari C. Buchanania lanzan Spreng (Chironji): A vulnerable multipurpose tree species in Vindhyan region. Journal of Pharmacognosy and Phytochemistry. 2018;7(5):833-6.

[11]. Anon. Wealth of India, A dictionary of Indian raw materials and Indian products, B revised ed., Publication and Information Directorate CSIR: New Delhi, 1952, 2.

[12]. Chauchan PS, Singh J, Kavita A. Chironji: A promising tree fruits of dry subtropics. Hort Flora Res Spectrum. 2012; 1(3):375-379.

[13]. Anonymous. The Wealth of India. Vol-IV. Publication and information Directorate (CSIR), New Delhi, 1992: 82-86, 308-10.

[14]. Mehta SK, Mukherjee S, Jaiprakash B. Preliminary Phytochemical Investigation on Leaves of Buchanania lanzan (Chironji). International Journal of Pharmaceutical Sciences. Review and Research. 2010; 3(2): 55-59.

[15]. Nasim KT, Arya R, Babu V, Ilyas M. Myricetin 3'Rhamnoside-3-Galactoside from Buchananza Lanzan (Anacardiaceae). Phytochemistry. 1992; 31(7): 2569-70.

[16]. Mehta SK, Jaiprakash B, Nayeem N. Isolation and phytochemical investigation on leaves of Buchanania lanzan (Chironji). Ann Biol Res 2011;2(3):469-73.

[17]. Banerjee SW, Bandyopadhyay AB. Buchanania lanzan spreng: $A$ veritable storehouse of phytomedicines. Asian Journal of Pharmaceutical and Clinical Research. 2015;8(5):18-22.

[18]. Tripathi MK, Kumar A, Mishra MC, Singh R. Preliminary Phytochemical Investigation and Pharmacognostic Study of Seeds of Buchanania lanzan Spreng. The Journal of Indian Botanical Society. 2016;95(3and4):246-55.

[19]. Patel J, Reddy V, Kumar GS, Prasad J, Krishna S. Pharmacognostic study of some important hepatoprotective plants. Journal of Pharmacognosy and Phytochemistry. 2016;5(6):75.
[20]. Pattnaik A, Sarkar R, Sharma A, Yadav KK, Kumar A, Roy P, Mazumder A, Karmakar S, Sen T. Pharmacological studies on Buchanania lanzan Spreng.-A focus on wound healing with particular reference to anti-biofilm properties. Asian Pacific journal of tropical biomedicine. 2013;3(12):96774.

[21]. Singh MK, Das BK, Patidar P. The effect of methanolic extract of Buchanania lanzan Spreng seeds on hematological indices. Indian journal of pharmacology. 2016;48(2):214.

[22]. Niratker C, Sailaja D. Preliminary phytochemical screening and evaluation of antimicrobial activity of Buchnania lanzan (chironji) from Chhattisgarh. World J Pharmaceu Res. 2014;3(9):514-22.

[23]. V. P. Nagulwar, S. A. Deshpande. Phytochemical screening and evaluation of pharmacological activities of Buchanania lanzan spreng leaves. International Journal of Pharmaceutical Sciences and Research.2020;11(1): 156-162.

[24]. Kodati D, Pareta SK, Patnaik A. Antidiarrhoeal activity of alcoholic extract of Buchanania lanzan Spreng. roots. Pharmacologyonline. 2010;3:720-6.

[25]. Kodati D, Pareta S, Patra KC. Antiulcer activity of ethanolic extract of Buchanania lanzan Spreg. Roots. Annals of biological research. 2010;1(4):234-9.

[26]. Jain R, Jain SK. Effect of Buchanania lanzan Spreng. bark extract on cyclophosphamide induced genotoxicity and oxidative stress in mice. Asian Pacific journal of tropical medicine. 2012;5(3):187-91.

[27]. Sushma N, Smitha PV, Gopal YV, Vinay R, Reddy NS, Mohan M, Raju B. Antidiabetic, antihyperlipidemic and antioxidant activities of Buchanania lanzan spreng methanol leaf extract in streptozotocin-induced types I and II diabetic rats. Tropical Journal of Pharmaceutical Research. 2013;12(2):221-6.

[28]. Mehta KS, Mukherjee S, Jaiprakash B. Antiinflammatory activity of the methanolic extract of Buchanania lanzan leaves by carrageenan-induced rat paw oedema method. Int J Pharm Sci Rev Res. 2011;6(2):144-6. 
[29]. Hullatti K, Manjunatha JR, Kuppasth IJ. Comparative Study on Diuretic Effect of Buchanania angustifolia Roxb., and Buchanania lanzan Spreng. Fruit Extracts and Fractions. Journal of Applied Pharmaceutical Science. 2014;4(8):59.

[30]. Mehmood AM, Hamid IR, Sharif A, Akhtar MF, Akhtar B, Saleem AM, Iqbal J, Shabbir M, Ali SA. Evaluation of anti-inflammatory, analgesic and antipyretic activities of aqueous and ethanolic extracts of seeds of Buchanania lanzan spreng. In animal models. Acta poloniae pharmaceutica. 2016;73(6):1601-8.

[31]. Roshani Y Vyavaharkar, Bs S Mangaonkar. Determination of antioxidant potential of Buchanania lanzan spreng. (chironji) seed extracts. International Journal of Advances in Pharmaceutical Sciences. 2015;6(4): 2964-2967.

[32]. Lopaczynski W, Zeisel SH. Antioxidant, programmed cell death and cancer. Nutr Res 2001;21:295-307.

[33]. Shailasree S, Ruma K, Prakash HS. Curative properties of Buchanania lanzan: As evaluated by its anti-oxidant, anti-inflammatory and DNA protective properties. J Nat Pharm. 2012;3:71-77.

[34]. Joshi H, Pagare M, Patil L, Kadam V. Cardioprotective Effect of Ethanolic Extract of Buchanania lanzan Spreng. Against Isoproterenol Induced Myocardial Infarction in Rats: A Biochemical, Electrocardiographic Evaluation. Research Journal of Pharmacy and Technology. 2012;5(2):263-6.

[35]. Reddy DS. Assessment of nootropic and amnestic activity of centrally acting agents. Indian J Pharmacol 1997;29:208-21.

[36]. Ellen YS, Kathryn MU. Donepezil: Anti cholinesterase inhibitor for Alzheimer's disease. Am J Health Syst Pharm 1997;54:2805-10.

[37]. Neelakanth MJ, Bhat MR, Taranalli AD, Veeresh B. Effect of Buchanania lanzan seeds on learning and memory in normal and memory deficit rats. J Res Pharm Biomed 2012;22(1):33-8.

[38]. Tyagi N. formulation and evaluation of Zidovudine nanosuspensions using a novel bio polymer from the seeds of Buchanania lanzan. Journal of Drug Delivery and Therapeutics. 2013;3(4):85-8.

[39]. Singh S, Bothara BS, Ayaz A. Formulation of oral mucoadhesive tablets using mucilage isolated from Buchanania lanzan spreng seeds. Int J Pharm Sci Nanotechnol. 2014;7(2):2494-503.

[40]. Tyagi y, madhav ns. Development, characterization, and evaluation of selegiline bionanosuspensions using Buchanania lanzan as biostabilizer. Development. 2019;12(2).

[41]. Tyagi N. A novel, potent, bio-film former from the seeds of Buchanania lanzan for formulating tobramycin occuserts. Int $\mathrm{J}$ Pharm Tech Res 2012;4(1):422-6.

[42]. Singh S, Bothara SB, Roshan PD, Naveen MK. Formulation and Ex-vivo Evaluation of Transdermal Patches of Glipizide using the Penetration Enhancer Buchanania lanzan (Spreng) Seed Oil. 2015;8(1):2768-2774.

\section{Cite this article as :}

Akila Elias, Prasanna V Habbu, Sudhir Iliger, "An Updated Review on Phyto-Pharmacological and Pharmacognostical Profile Of Buchanania Lanzan : A Pharmacognostic Miracle Herb", International Journal of Scientific Research in Science and Technology (IJSRST), Online ISSN : 2395-602X, Print ISSN : 23956011, Volume 8 Issue 6, pp. 298-310, NovemberDecember 2021. Available at doi : https://doi.org/10.32628/IJSRST218642 Journal URL : https://ijsrst.com/IJSRST218642 